\title{
Storage Studies of Low Salt Pork Sausages and Low Salt Pork Curry Under Refrigerated Conditions
}

\author{
E. Nagamallika, M. SahityaRani* and B. Eswara Rao
}

Department of Livestock Products Technology, NTR College of Veterinary Science, Gannavaram, Sri Venkateshwara Veterinary University, 521102, Andhra Pradesh, India

*Corresponding author

\begin{tabular}{|c|c|}
\hline & A B S T R A C T \\
\hline Keywords & $\begin{array}{l}\text { A study was conducted by aiming at reducing salt levels in pork sausages and curry } \\
\text { without affecting the quality and shelf stability of the products. Low salt pork sausages and }\end{array}$ \\
\hline $\begin{array}{l}\text { Ajwain, Low salt, } \\
\text { Oregano, Pork } \\
\text { sausages, Pork } \\
\text { curry, Potassium } \\
\text { chloride, Sensory } \\
\text { quality }\end{array}$ & $\begin{array}{l}\text { curry were standardized with } 0.7 \% \text { potassium chloride and } 0.5 \% \text { oregano (T1), T2 with } \\
0.7 \% \text { potassium chloride and } 0.5 \% \text { ajwain and T3 with oregano and ajwain without any } \\
\text { salt incorporation and subjected to storage studies, under refrigerated temperature. The } \\
\text { results of the study revealed that the replacement of sodium chloride with potassium } \\
\text { chloride and herbal spices namely oregano and ajwain was proved effective and these } \\
\text { spices successfully masked the bitter and astringent flavour of potassium chloride. T1 and }\end{array}$ \\
\hline Article Info & $\begin{array}{l}\mathrm{T} 2 \text { recorded good emulsion stability, lower } \mathrm{pH} \text { and lower Thiobarbituric acid values. No } \\
\text { significant difference was found between the treatments in terms of their microbiological }\end{array}$ \\
\hline $\begin{array}{l}\text { Accepted: } \\
\text { 20 June } 2018 \\
\text { Available Online: } \\
\text { 10 July } 2018\end{array}$ & $\begin{array}{l}\text { and sensory quality. T3 was the least accepted formulation, though there was non- } \\
\text { significant difference in overall acceptability. It can be concluded that, the replacement of } \\
50 \% \text { sodium chloride content by potassium chloride promoted healthier characteristics in } \\
\text { pork sausages and curry without effecting the physico-chemical quality and the }\end{array}$ \\
\hline
\end{tabular}

\section{Introduction}

Meat and meat products are important sources of proteins and essential amino acids, fats, iron, zinc, conjugated linoleic acid and B1, B2, B6 and B12 vitamins. However meat consumption had been criticized because it contains high levels of sodium and fat and also little or no fibre or calcium. Meat contains 50$90 \mathrm{mg}$ of sodium per $100 \mathrm{gms}$ of meat but processed meat products contribute rather a high amount of sodium than this. Usually 2.0$4.0 \%$ sodium chloride is added to sausage mince and these values increase in final product to drying process. In addition to sodium chloride other salts such as nitrite, ascorbate, and erythroborate may provide sodium (Stahnke and Tjener, 2007).

It has been established that the consumption of more than six grams of sodium chloride per day per person is associated with an age increase in blood pressure (BP) and it had been recommended that total amount of dietary salt should be 5-6grams per day, thus there is a raising demand for low sodium 
functional food products which emerged as major concept of research in present era. Reduction of sodium chloride in the original formulations may reduce the taste, flavour, microbiological and physico-chemical stability of the product and may alter the typical textural properties of meat products (Terrell, 1983), (Ruusunen and Puolanne, 2005). Further in case of emulsified meat products it may alter the extraction of myofibrillar proteins affecting the water holding capacity, fat binding properties and formulations of stable gels in cooking stage (Desmond, 2006). Considerable attempts were made for production of low sodium meat products with reduction of dietary salt intake and replacing the sodium chloride content with other ingredients like potassium, calcium, magnesium chloride salts (Horita et al., 2011). An attempt was made in the present research work to establish a promising low sodium product with replacement of potassium chloride, herb and spice blends i.e. ajwain and oregano in pork sausages and curry.

\section{Materials and Methods}

Meat from ham portion of carcasses were collected from experimental abattoir, Department of Livestock Products Technology, NTR College of Veterinary Sciences, Gannavaram and was minced by using a meat mincer (Sirman). Sausages and curry were prepared with replacement of sodium chloride content using potassium chloride $(\mathrm{KCl})$, oregano, ajwain and three formulation were produced i.e. with addition of potassium chloride and ajwain (T1), potassium chloride and oregano (T2), ajwain and oregano (T3) along with the control formulation containing sodium chloride without any salt replacers were presented in Table 1 and 2. The level of incorporation of each spice was determined by trial and error and each herbal spice was added at a level of 0.5 per cent into each formulation along with
0.7 per cent potassium chloride. All the formulations of pork sausages and curry were subjected to sensory evaluation by semi trained taste panel were evaluated for colour, flavour, tenderness, saltiness, juiciness, and overall acceptability on a 9 point hedonic scale. Results were analysed using statistical version SPSS 24.0 based on versions of Snedecor and Cochran (1994).

\section{Results and Discussion}

\section{Percent cooking yield}

The percent cooking yield of low salt pork sausages and curry of different formulations at different storage intervals under refrigerated storage $\left(4 \pm 1^{\circ} \mathrm{C}\right)$ were represented in Figure 1 . The percent cooking yield of low salt pork sausages ranged from 86.47 to 80.02 (control), 82.84 to 78.42 (T1), 82.50 to 74.81 (T2) and 82.10 to 70.09 (T3) on $0^{\text {th }}, 5^{\text {th }}, 10^{\text {th }}$ and $15^{\text {th }}$ day, respectively. Whereas it ranged from 90.45 to 80.34 (control), 84.30 to 78.12 (T1), 85.21 to 75.46 (T2) and 85.62 to 74.52 (T3) on $0^{\text {th }}, 5^{\text {th }}, 10^{\text {th }}$ and $15^{\text {th }}$ day, respectively in pork curry. Similarly, Horita et al., (2011) in low sodium reduced fat mortadella prepared with blends of calcium, magnesium and potassium chloride, Ruusunen et al., (2005) in ground meat patties and Tamm et al., (2016) in cooked ham also recorded reduced cooking yields with reduction of salt.

\section{Emulsion stability}

Mean Emulsion stability values of control formulation under refrigeration at $0,5^{\text {th }}, 10^{\text {th }}$ and $15^{\text {th }}$ day were $97.13,96.89,94.52$ and 93.78 , respectively.

The significant influence on emulsion stability might be due to the presence (or) absence of ionic force properties of potassium chloride which are similar to those of sodium chloride (Carraro et al., 2012). The results were similar to the findings of Canto et al., (2014). 
pH

The $\mathrm{pH}$ values of low salt pork sausages and curry of different formulations at different storage intervals under refrigerated storage $\left(4 \pm 1^{\circ} \mathrm{C}\right)$ were represented in figure 3 . Mean $\mathrm{pH}$ values of control formulation under refrigeration at $0,5^{\text {th }}, 10$ th and $15^{\text {th }}$ day were 5.63, 5.42, 5.43 and 5.50 in sausages and 5.54, $5.61,5.52$ and 5.56 in curry respectively. The $\mathrm{pH}$ values all treatments differed significantly $(\mathrm{P}<0.05)$ with control in case of pork sausages. The value of $\mathrm{pH}$ in low salt pork curry were non-significantly $(\mathrm{P}<0.05)$ affected by the formulation. During storage period, there was a significantly $(\mathrm{P}<0.05)$ decrease in $\mathrm{pH}$ of sausages and a significantly $(\mathrm{P}<0.05)$ increase in $\mathrm{pH}$ of curry treatments at the end of storage. The phenol, thymol and carvacrol present in ajwain and oregano might be the contributing factor for the lower $\mathrm{pH}$ values. The results were comparable to those of Verma et al., (2010) in chicken nuggets and Ruusunen et al., (2005) in meat patties with sodium replacement.

Thiobarbituric acid reactive substances (TBARS)

The Mean values of TBARS of low salt pork sausages and curry of different formulations at different storage intervals under refrigerated storage $\left(4 \pm 1^{\circ} \mathrm{C}\right)$ were represented in figure 4 .

The mean TBARS values of various formulations ranged from 0.097, 0.086, 0.083 and 0.076 in control, T1, T2 and T3 in pork sausages and 0.097, 0.095, 0.089 and 0.083 in control, T1, T2 and T3 in pork curry on $0^{\text {th }}$, $5^{\text {th }}, 10^{\text {th }}$ and $15^{\text {th }}$ day, respectively. The mean TBARS value of all the treatments were significantly $(\mathrm{P}<0.05)$ affected with the type of formulation in both sausages and curry. The TBARS value of sausages were significantly $(\mathrm{P}<0.05)$ increased towards the end of storage period. Light induced oxidation might have increased the values of the product, during the later phases of storage. Herbal spice blend incorporated had significant influence on the TBARS values of low salt meat product and preparation and significantly reduced the fat oxidation as indicated by a slow increase in TBARS values of sausages and curry. These results were in accordance with those of Horita et al., (2016) in Brazilian low sodium frankfurters with incorporation of garlic, Raeisi et al., (2016) in rainbow trout fillets coated with ajwain, Fasseas et al., (2007) in bovine and porcine meat treated with oregano.

Table.1 Formulation of pork sausages with different salt replacers

\begin{tabular}{|l|c|c|c|c|}
\hline \multicolumn{1}{|c|}{ Ingredients \% } & Control (C) & $\begin{array}{c}\mathrm{KCl}+ \\
\text { Ajwain }(\mathrm{T} 1)\end{array}$ & $\begin{array}{c}\mathrm{KCl}+ \\
\text { Oregano (T2) }\end{array}$ & $\begin{array}{c}\text { Ajwain+Oregano } \\
(\mathrm{T} 3)\end{array}$ \\
\hline pork & 74 & 74 & 74 & 74 \\
\hline Spice mix & 3 & 3 & 3 & 3 \\
\hline Condiments & 4 & 4 & 4 & 4 \\
\hline Binder & 3 & 3 & 3 & 3 \\
\hline Salt & 1.2 & -- & -- & -- \\
\hline Potassium & -- & 0.7 & 0.7 & -- \\
\hline chloride & & & & 0.6 \\
\hline Oregano & -- & -- & 0.5 & 0.6 \\
\hline Ajwain & -- & 0.5 & -- & 10 \\
\hline Chilled water & 10 & 10 & 10 & 5 \\
\hline Fat & 5 & 5 & 5 & \\
\hline
\end{tabular}


Table.2 Formulation of pork curry with different salt replacers

\begin{tabular}{|l|c|c|c|c|}
\hline $\begin{array}{c}\text { Ingredients } \\
\%\end{array}$ & Control (C) & $\begin{array}{c}\mathrm{KCl}+\text { Ajwain } \\
(\mathrm{T} 1)\end{array}$ & $\begin{array}{c}\mathrm{KCl}+\text { Oregano } \\
(\mathrm{T} 2)\end{array}$ & $\begin{array}{c}\text { Ajwain+ } \\
\text { Oregano (T3) }\end{array}$ \\
\hline pork & 74 & 74 & 74 & 74 \\
\hline Spice mix & 3 & 3 & 3 & 3 \\
\hline Condiments & 7 & 7 & 7 & 7 \\
\hline Salt & 1.2 & -- & -- & -- \\
\hline $\begin{array}{l}\text { Potassium } \\
\text { chloride }\end{array}$ & -- & 0.7 & 0.7 & - \\
\hline Oregano & -- & -- & 0.5 & 0.6 \\
\hline Ajwain & -- & 0.5 & -- & 0.6 \\
\hline Warm water & 10 & 10 & 10 & 10 \\
\hline Fat & 5 & 5 & 5 & 5 \\
\hline
\end{tabular}

Fig.1 Mean Percent cooking yield values of low salt pork sausages and curry as influenced by different formulations

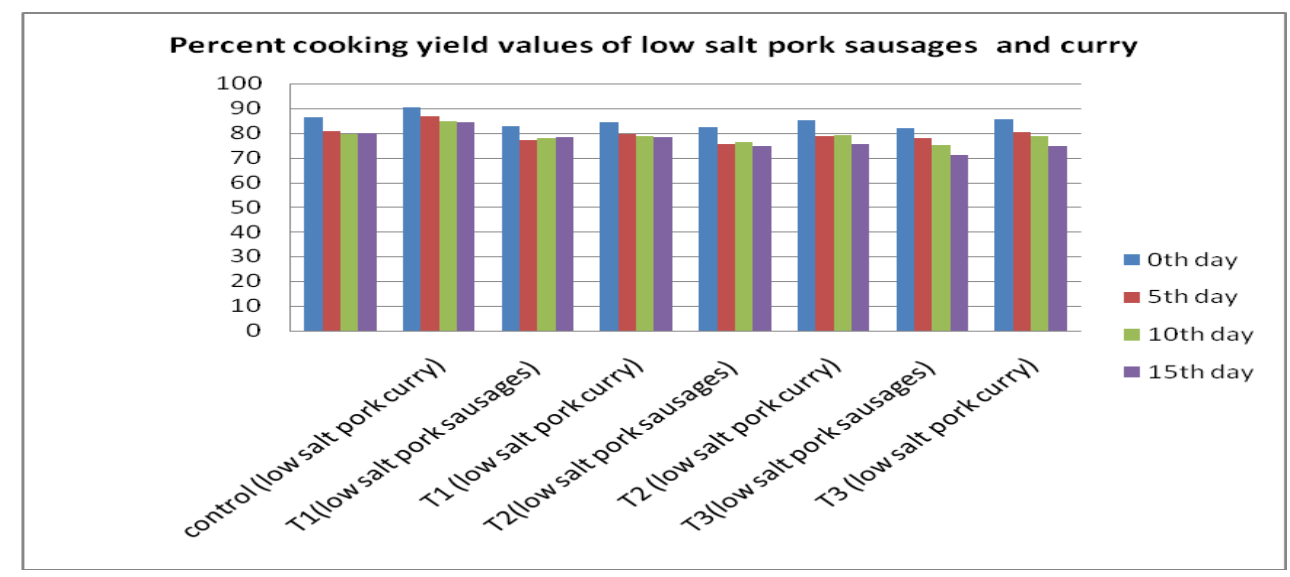

Fig.2 Mean emulsion stability values of low salt pork sausages as influenced by different formulations and storage periods at refrigerated storage $\left(4 \pm 1^{\circ} \mathrm{C}\right)$

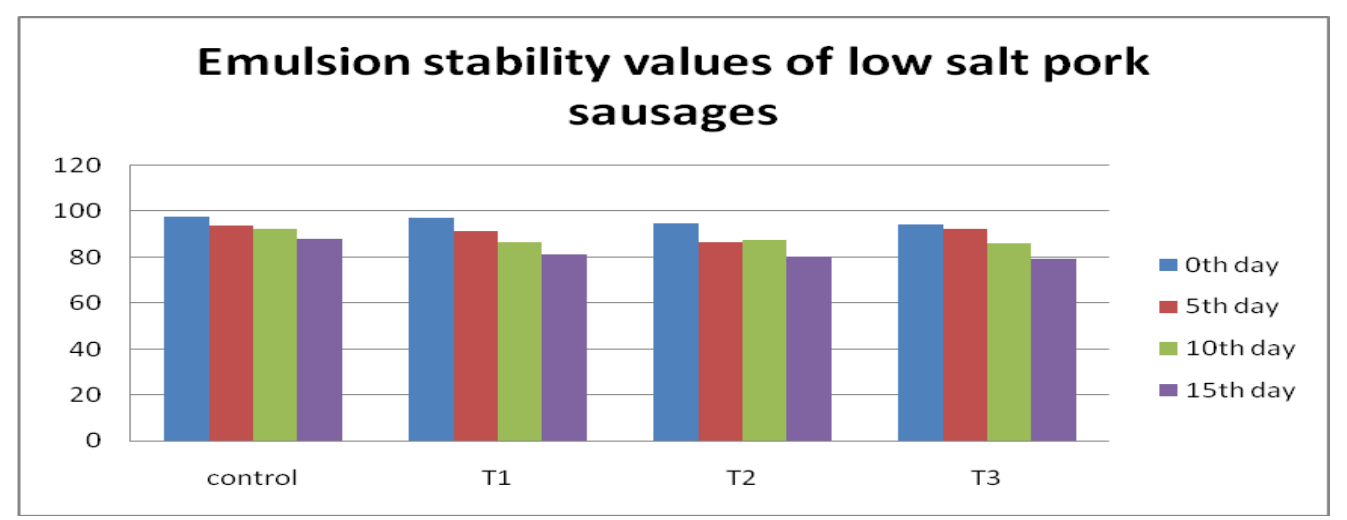


Fig.3 Mean pH values of low salt pork sausages and curry as influenced by different formulations and storage periods at refrigerated storage $\left(4 \pm 1^{\circ} \mathrm{C}\right)$

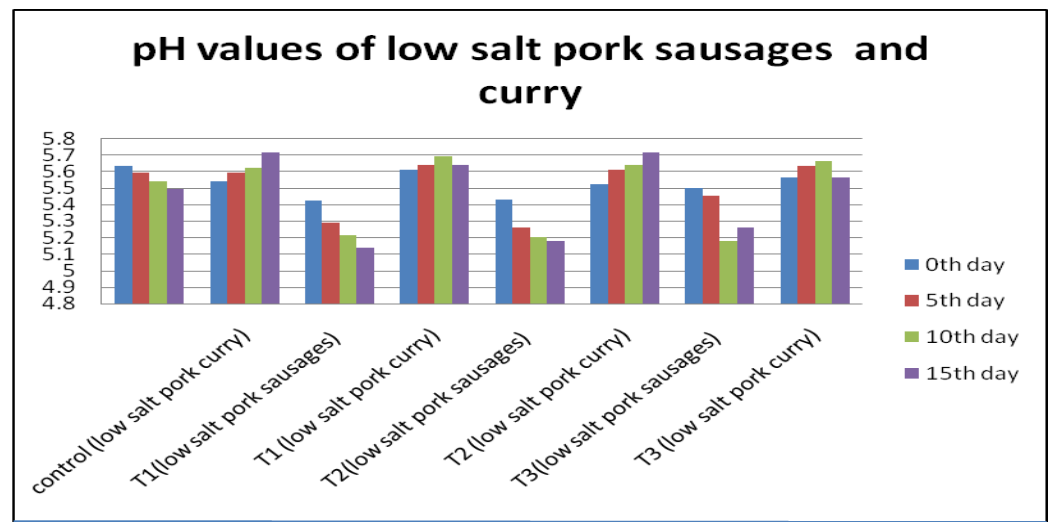

Fig.4 Mean TBARS values of low salt pork sausages and curry as influenced by different formulations and storage periods at refrigerated storage $\left(4 \pm 1^{\circ} \mathrm{C}\right)$

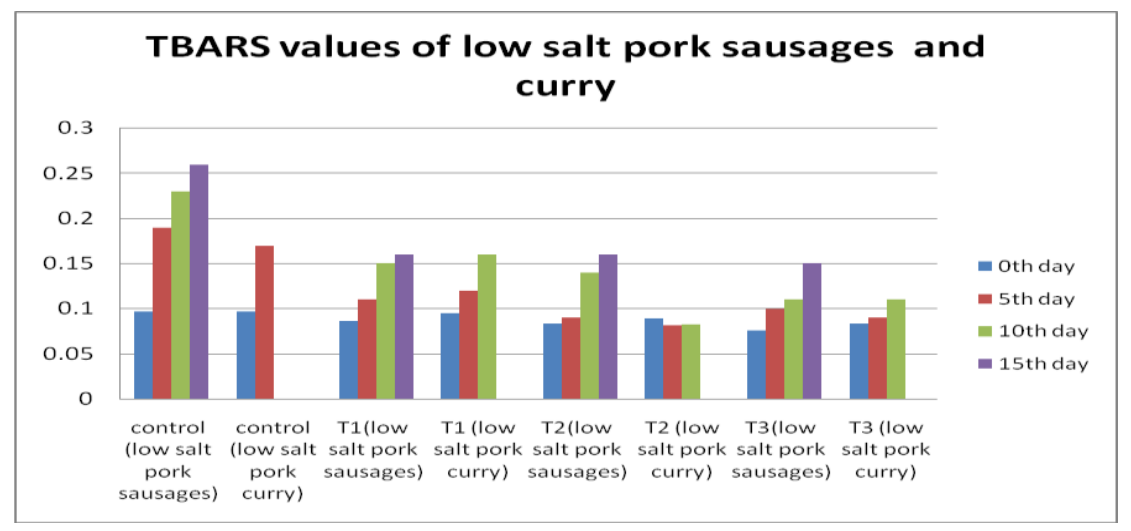

Fig.5 Mean Total plate counts of low salt pork sausages and curry as influenced by different formulations and storage periods at refrigerated storage $\left(4 \pm 1^{\circ} \mathrm{C}\right)$

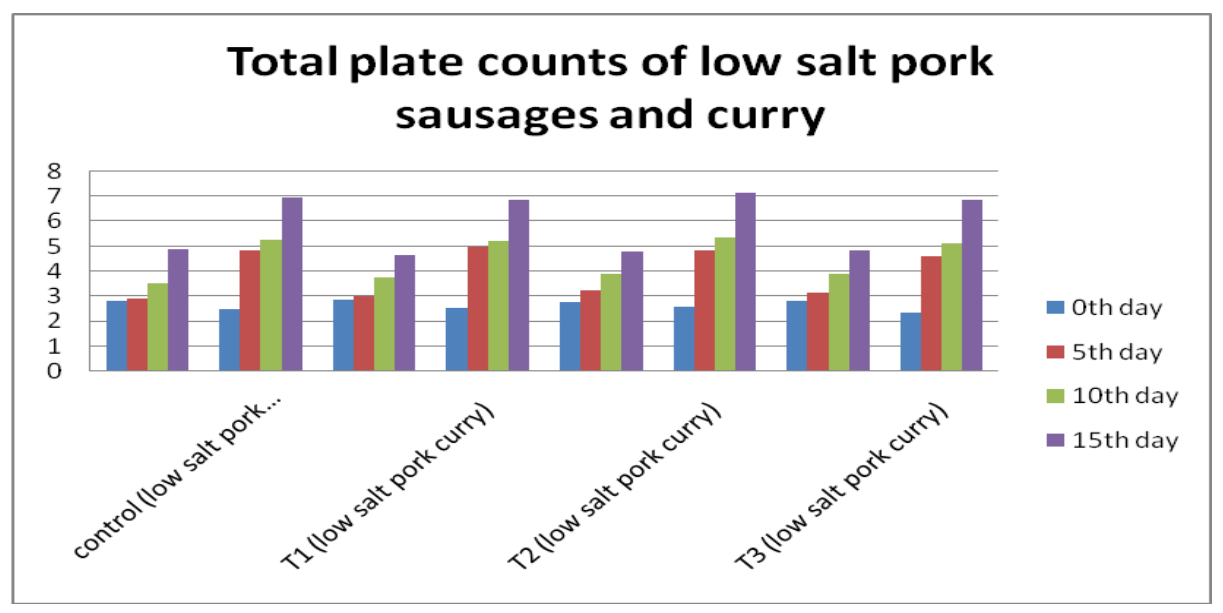


Fig.6 Mean colour values of low salt pork sausages and curry as influenced by different formulations and storage periods at refrigerated storage $\left(4 \pm 1^{\circ} \mathrm{C}\right)$

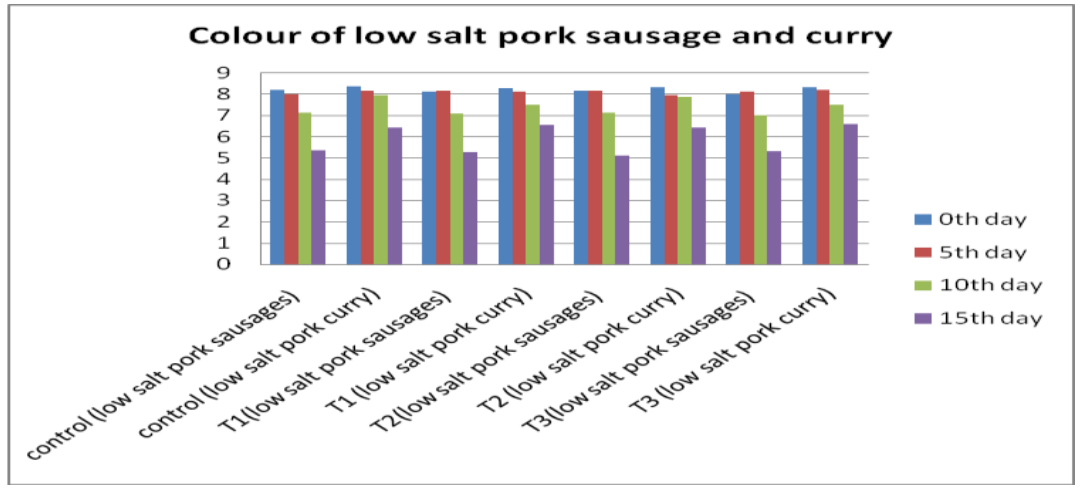

Fig.7 Mean flavour scores of low salt pork sausages and curry as influenced by different formulations and storage periods at refrigerated storage $\left(4 \pm 1^{\circ} \mathrm{C}\right)$

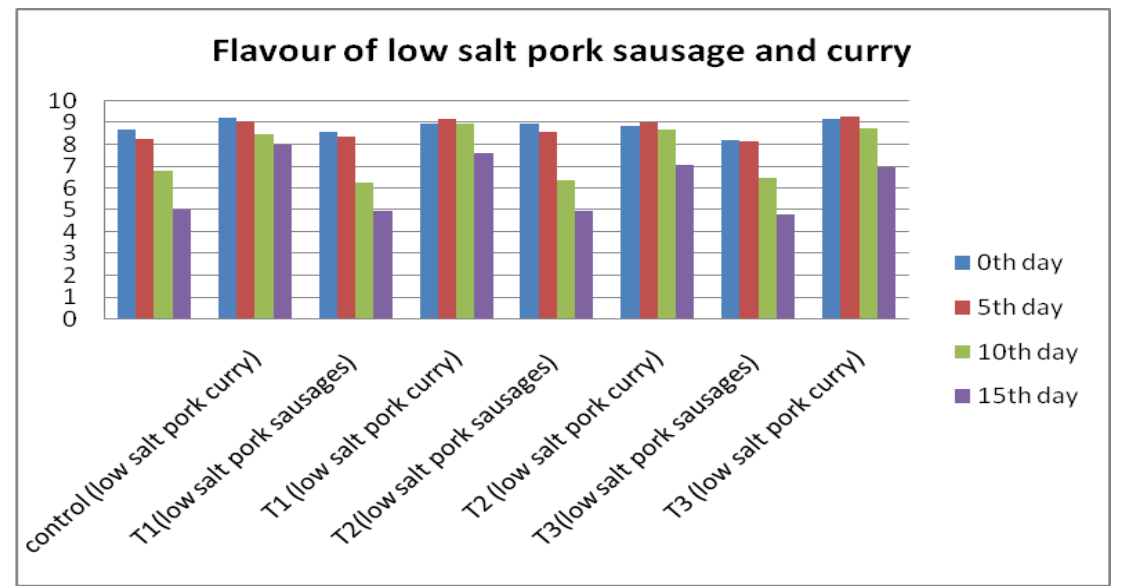

Fig.8 Mean juiciness scores of low salt pork sausages and curry as influenced by different formulations and storage periods at refrigerated storage $\left(4 \pm 1^{\circ} \mathrm{C}\right)$

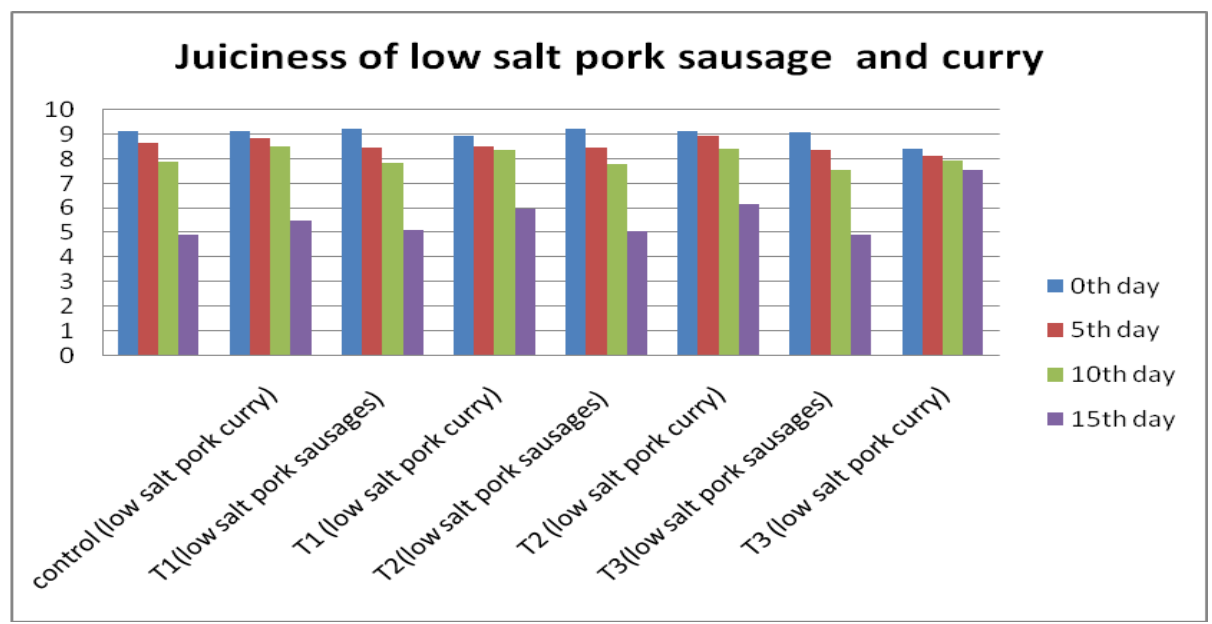


Fig.9 Mean tenderness scores of low salt pork sausages and curry as influenced by different formulations and storage periods at refrigerated storage $\left(4 \pm 1^{\circ} \mathrm{C}\right)$

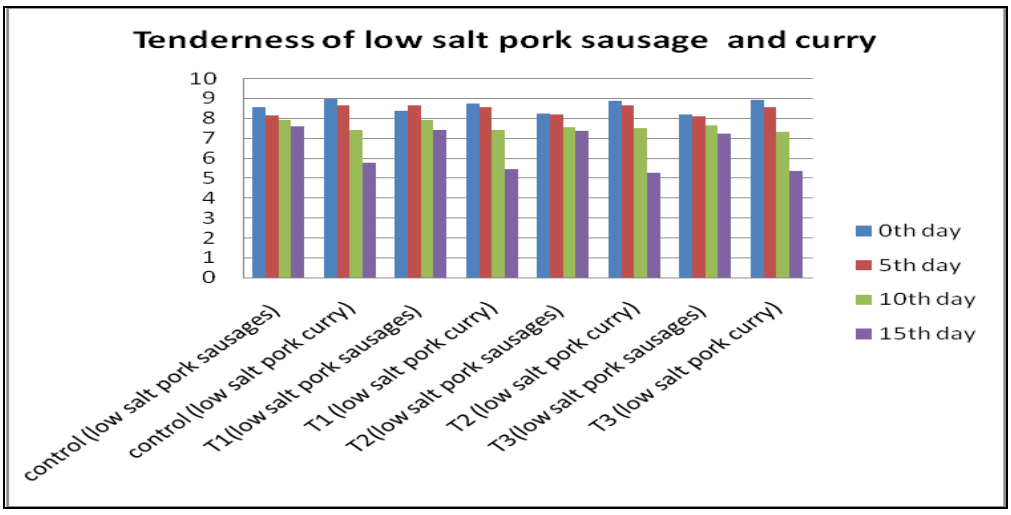

Fig.10 Mean saltiness scores of low salt pork sausages and curry as influenced by different formulations and storage periods at refrigerated storage $\left(4 \pm 1^{\circ} \mathrm{C}\right)$

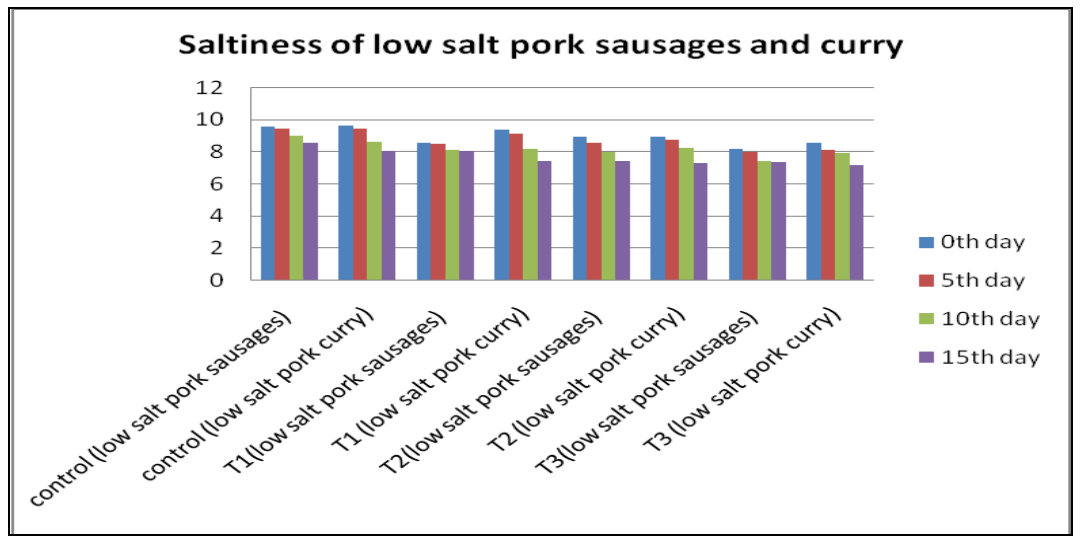

Fig.11 Mean overall acceptability scores of low salt pork sausages and curry as influenced by different formulations and storage periods at refrigerated storage $\left(4 \pm 1^{\circ} \mathrm{C}\right)$

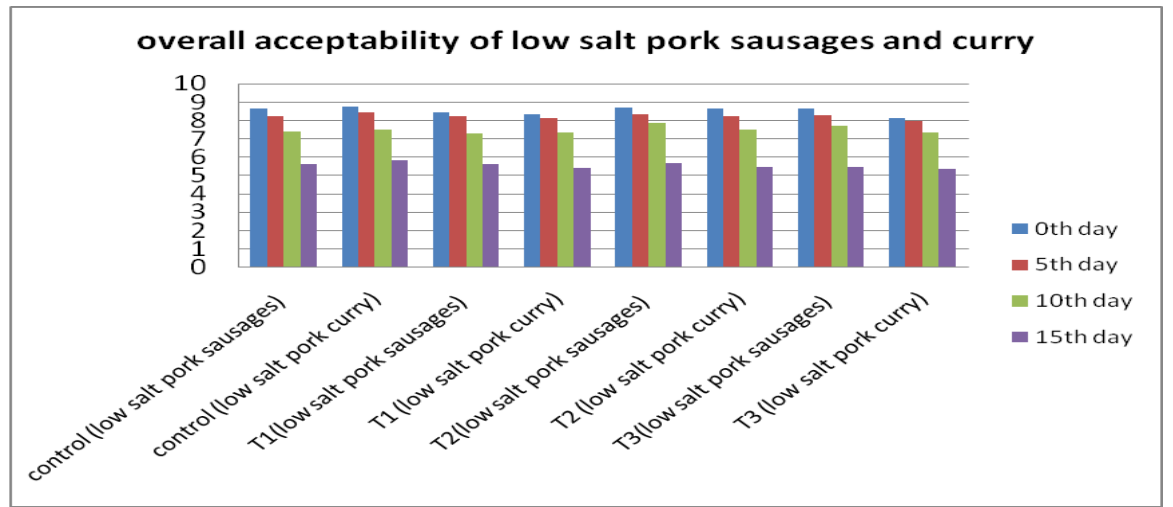




\section{Total plate count}

The Mean values of Total plate count of low salt pork sausages and curry of different formulations at different storage intervals under refrigerated storage $\left(4 \pm 1^{\circ} \mathrm{C}\right)$ were represented in figure 5 .

The lower in initial bacterial counts might be due to the effective thermal process and presence of herbal spices i.e. Oregano and Ajwain containing thymol and carvacrol which have an inhibitory effect on the development of spoilage microorganisms. These results are comparable to those of Carraro et al., (2012) in low salt bologna sausages added with herbs and spices, Aaslyng et al., (2014) in hot dogs, Horita et al., (2016) in Brazilian low sodium frankfurters added with garlic and Raeisi et al., (2016) in rainbow trout fillets added with ajwain.

\section{Sensory evaluation}

The Mean values of colour, flavour, juiciness, Tenderness, saltiness and Overall acceptability of low salt pork sausages and curry of different formulations at different storage intervals under refrigerated storage $\left(4 \pm 1^{\circ} \mathrm{C}\right)$ were represented in figure $6,7,8,9$, 10 and 11 , respectively.

In sensory evaluation the colour of all treatments was non-significantly affected in type of formulation in pork sausages. Whereas in pork curry the colour of formulation without salt recorded lower colour score. This might be due to the action of ingredients on the final colour of cooked products in pigmentary changes that take place during cooking.

Flavour is a multi-sensory perception produced through the integration of the senses of taste, smell and the trigeminal (Auvray and
Spence 2008). Ruusunen et al., ( 2005) in low sodium ground meat patties, Carraro et al., (2012) in low sodium bologna sausages added with herbs and spices, Yogesh et al., (2012) in low salt chicken nuggets also observed similar trends.

Saltiness scores of all formulations did not differ significantly. Oregano and ajwain along with potassium chloride in the treatment groups might have improved the palatability of the products.

The juiciness scores were non significantly affected by salt content which can be attributed to the ability of the added ingredients to maintain the ionic force properties similar to those of sodium chloride there by maintaining the ability of meat proteins to entrap water.

Tenderness in meat products is rated as most important by the average consumer irrespective of type of product the tenderness scores differed non-significantly between formulations. This might be due to nonsignificant difference that existed in juiciness which was being maintained by the ionic force properties.

However due to maintenance of juiciness, tenderness and flavour in salt replaced formulations, the overall acceptability of the formulations differed non-significantly.

This can be attributed to the properties of potassium chloride, oregano and ajwain to maintain the ionic force properties, protein binding and salt replacement quality. The results of sensory analysis of present study correlated with Carraro et al., (2012) in low sodium bologna sausages incorporated with herbs and spices, Horita et al., (2016) in Brazilian low sodium frankfurters added with garlic and Ruusunen et al., (2005) in low sodium ground meat patties. 


\section{References}

Aaslyng, M. D., C. Vestergard and Koch, A. G. 2014. The effect of salt reduction on sensory quality and microbial growth in hotdog sausages bacon ham and salami. Meat Science. 96:47-55.

Auvray, M., and Spence, C. 2008.The multisensory perception of flavor. Consciousness and cognition. 17(3): 10161031.

Carraro, C. I., R. Machado, V. Espindola, P. C. B. Campagnol and Pollonio M. A. R. 2012. The effect of sodium reduction and the use of herbs and spices on the quality and safety of bologna sausage. Food Science and Technology. 32(2): 289-297.

Canto, A. C., B. R. C. Lima, S. P. Suman, C. A. Lazaro, M. L. G. Monteiro, J. C. A. Conte and Silva T. J. 2014. Physico-chemical and sensory attributes of low-sodium restructured caiman steaks containing microbial transglutaminase and salt replacers. Meat science. 96(1): 623-632.

Desmond, E., 2006. Reducing Salt- A challenge for Meat industry. Meat Science. 74: 188196.

Fasseas, M. K., K. C. Mountzouris, P. A. Tarantilis, M. Polissiou and Zervas G. 2007. Antioxidant activity in meat treated with oregano and sage essential oils. Food Chemistry. 106: 1188-1194.

Horita, C. N., M. A. Morgano, R. M. S. Celeghini and Pollonio M. A. R. 2011. Physicochemical and sensory properties of reducedfat mortadella prepared with blends of calcium magnesium and potassium chloride as partial substitutes for sodium chloride. Meat Science. 89(4): 426-433.

Horita, C. N., A. M. Farías-Campomanes, T. S. Barbosa, E. A. Esmerino, A. G. da Cruz, H. M. A. Bolini and Pollonio M. A. R. 2016. The antimicrobial antioxidant and sensory properties of garlic and its derivatives in Brazilian low-sodium frankfurters along shelf-life. Food Research International. 84: 18.

Ruusunen, M., and Puolanne, E. 2005. Reducing sodium intake from meat products. Meat science. 70(3): 531-541.

Raeisi, S., M. Sharifi-Rad, S. Y. Quek, B. Shabanpour and Sharifi-Rad J. 2016. Evaluation of antioxidant and antimicrobial effects of shallot (Allium ascalonicum $\mathrm{L}$ ) fruit and ajwain (Trachyspermum ammi (L Sprague) seed extracts in semi-fried coated rainbow trout (Oncorhynchusmykiss) fillets for shelf-life extension. LWT-Food Science and Technology. 65: 112-121.

Snedecor, G. W., and Cochran, W. G. 1994. Statistical Methods. New Delhi: Oxford and IBM Publications. 265.

Stahnke, L. H., and Tjener, K. 2007. Influence of processing parameters on cultures performance. Handbook of fermented meat and poultry 1: 187-194.

Terrell, R. N. 1983. Reducing the sodium content of processed meats. Food Technology:66-71

Tamm, A., T. Bolumar, B. Bajovic and Toepfl S. 2016. Salt reduction in cooked ham by a combined approach of high pressure treatment and the salt replacer $\mathrm{KCl}$. Innovative Food Science \& Emerging Technologies. 36: 294-302.

Verma, A. K., B. D. Sharma and Banerjee R. 2010. Effect of sodium chloride replacement and apple pulp inclusion on the physicochemical textural and sensory properties of low fat chicken nuggets. LWT-Food Science and Technology. 43(4): 715-719.

Yogesh, K., T. Ahmad, G. Manpreet, K. Mangesh and Das P. 2013. Characteristics of chicken nuggets as affected by added fat and variable salt contents. Journal of food science and technology. 50(1): 191-196.

\section{How to cite this article:}

Nagamallika, E., M. SahityaRani and Eswara Rao, B. 2018. Storage Studies of Low Salt Pork Sausages and Low Salt Pork Curry Under Refrigerated Conditions. Int.J.Curr.Microbiol.App.Sci. 7(07): 2765-2773. doi: https://doi.org/10.20546/ijcmas.2018.707.323 